Financiamento e conflito de interesses

\begin{tabular}{|c|c|c|c|c|c|c|c|}
\hline $\begin{array}{l}\text { Membro do grupo } \\
\text { de autores }\end{array}$ & $\begin{array}{l}\text { Local de } \\
\text { trabalho }\end{array}$ & $\begin{array}{l}\text { Verba de } \\
\text { pesquisa }\end{array}$ & $\begin{array}{c}\text { Outro apoio à } \\
\text { pesquisa ou educação } \\
\text { médica continuada }^{2}\end{array}$ & $\begin{array}{c}\text { Honorários } \\
\text { de } \\
\text { palestrantes }\end{array}$ & $\begin{array}{l}\text { Participação } \\
\text { acionária }\end{array}$ & $\begin{array}{l}\text { Consultor/ } \\
\text { conselho } \\
\text { consultivo }\end{array}$ & Outro $^{3}$ \\
\hline $\begin{array}{l}\text { Alcina Juliana Soares } \\
\text { Barros }\end{array}$ & UFCSPA & - & - & - & - & - & - \\
\hline $\begin{array}{l}\text { Lisieux Elaine de } \\
\text { Borba Telles }\end{array}$ & $\begin{array}{l}\text { IPFMC } \\
\text { UFCSPA }\end{array}$ & - & - & - & - & - & - \\
\hline $\begin{array}{l}\text { Pedro Henrique } \\
\text { Iserhard Zoratto }\end{array}$ & IPFMC & - & - & - & - & - & - \\
\hline $\begin{array}{l}\text { Marília Alves da Luz } \\
\text { Hentschel }\end{array}$ & IPFMC & - & - & - & - & - & - \\
\hline $\begin{array}{l}\text { Larissa Melgarejo } \\
\text { Santarém }\end{array}$ & IPFMC & - & - & - & - & - & - \\
\hline \multicolumn{8}{|l|}{$\begin{array}{l}{ }^{*} \text { Modesto } \\
\text { ** Significativa }\end{array}$} \\
\hline
\end{tabular}

Referências

1. Meloy JR. The nature and dynamics of sexual homicide: an integrative review. Aggression violent behavior. 2000;5(1):1-22.

2. Telles LEB. Perícias de responsabilidade penal realizadas no Instituto Psiquiátrico Forense. Multijuris: Primeiro Grau em Ação. 2007;2(3):44-9.

3. Baltieri DA, Andrade AG. Comparing serial and nonserial sexual offenders: alcohol and street drug consumption, impulsiveness and history of sexual abuse. Rev Bras Psiquiatr. 2008;30(1):25-31.

\section{Mania switch induced by amantadine in bipolar disorder: report of three cases}

\section{Virada maníaca induzida pela amantadina no transtorno bipolar: relato de três casos}

Dear Editor,

Bipolar disorder (BD) is often a severe and chronic disease. It has been shown that subjects with $\mathrm{BD}$ present cognitive impairment during the acute phase of the disease and remission, which seems to worsen with the recurrence of episodes. Available treatments are successful in reducing symptoms in acute mania and depression. However, their effects in the functional recovery of patients are minor. As previously shown in schizophrenia $(\mathrm{SZ}){ }^{1} \mathrm{BD}$ is associated with cognitive impairment (as seen in psychometric tests), neuroanatomical changes (evidenced in imaging studies), and neurotransmission dysregulation, such as in the case of glutamate. ${ }^{2}$ It has also been demonstrated that serum levels of brain-derived neurotrophic factor (BDNF), which
4. Stone MH. Sexual sadism: a portrait of evil. J Am Acad Psychoanal Dyn Psychiatry. 2010;38(1):133-57.

5. Folino JO. Estudios Argentino sobre homicidas. In: Folino JO, EscobarCórdoba F, editors. Estudios sobre homicidios: perspectivas forenses, clinica y epidemiológica. La Plata: Libreria Editora Platense; 2009. p.65-152.

is a protein related to neuroplasticity, are decreased during $\mathrm{BD}$ mood episodes. ${ }^{3}$

The adjunctive use of amantadine, a memantine derivative, has shown to be conducive to cognitive improvement in subjects with $\mathrm{SZ}^{4}$ and BD. ${ }^{5}$ This is so because amantadine has several properties: a) it increases the monoaminergic tonus via dopamine, norepinephrine, and serotonin in the amygdala and hippocampus b) has an antidepressant activity c) directly modulates glutamate as a partial agonist of $\mathrm{N}$-methyl-D-aspartate (NMDA) receptors, and d) contributes to BDNF increase and stabilizes the neuronal membrane. Amantadine use in patients with $\mathrm{BD}$ has not been associated with mood swings. ${ }^{5}$

We evaluated the use of amantadine adjunctive therapy for improving the cognitive impairment of three euthymic DSM-IV BD type I subjects who presented with a standard clinical pattern of cognitive and behavioral impairment or who were unable to live autonomously. ${ }^{3}$ Subjects gave informed consent for the experimental use of amantadine administered at increased doses of up to $400 \mathrm{mg}$ over a period of 8 weeks. Patients were evaluated by means of a psychiatric interview and their clinical response was assessed using the Young Mania Rating Scale (YMRS) and the 17-item Hamilton Depression Scale (HAMD). The three cases are illustrated in Table 1. All subjects had mania switches and the consequent worsening of cognitive impairment. Subject 3 presented a slightly different evolution, since it tolerated $200 \mathrm{mg}$ 


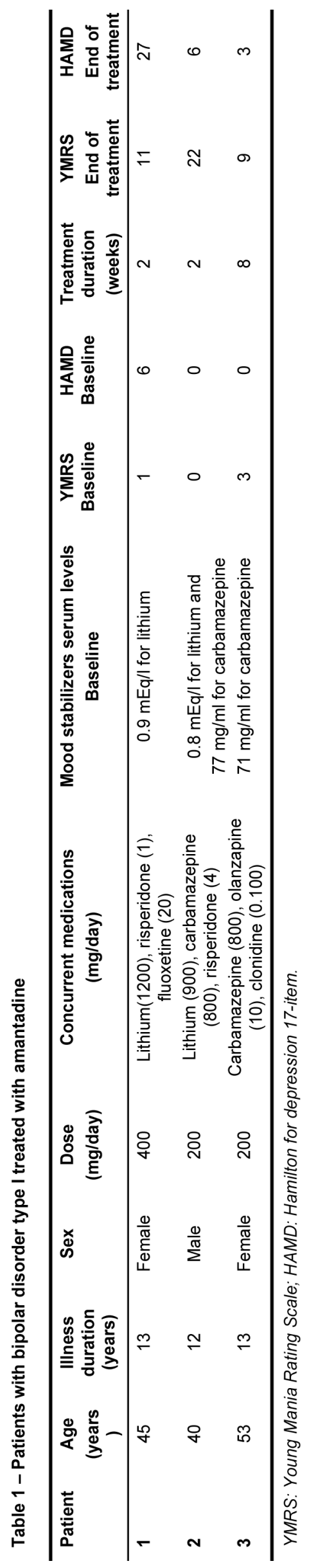

of amantadine for up to 2 weeks and showed some level of cognitive improvement. However, after 8 weeks of treatment, this subject presented with a mania switch associated with cognitive worsening. As a result of that, the administration of amantadine was discontinued.

Although amantadine may improve cognition by acting as a partial agonist at NMDA receptors, it increases the monoaminergic tonus of the amygdala and hippocampus. This may explain the mania switch seen in our subjects. Although subject 3 presented a different evolution, the reason for this remains unclear. This difference in evolution could be attributed to a better disease course or the antipsychotic profile of olanzapine, which this patient made use of while the other two subjects made use of risperidone. In contrast with the findings of Ohlmeier et al., 5 our results do not support the use of amantadine in BD. Further studies are required to evaluate possible treatments to improve functional outcomes in BD.

Leonardo A. Sodré, Joana Bücker, Karine Zortéa, Mireia F. Sulzbach-Vianna, Clarissa Severino Gama Hospital de Clínicas de Porto Alegre (HCPA), Universidade Federal do Rio Grande do Sul (UFRGS),

Porto Alegre, RS, Brazil 


\section{Disclosures}

\begin{tabular}{|c|c|c|c|c|c|c|c|}
\hline $\begin{array}{l}\text { Writing group } \\
\text { member }\end{array}$ & Employment & $\begin{array}{l}\text { Research } \\
\text { grant }^{1}\end{array}$ & $\begin{array}{l}\text { Other research grant or } \\
\text { medical continuous } \\
\text { education }{ }^{2}\end{array}$ & $\begin{array}{l}\text { Speaker's } \\
\text { honoraria }\end{array}$ & $\begin{array}{l}\text { Ownership } \\
\text { interest }\end{array}$ & $\begin{array}{l}\text { Consultant/ } \\
\text { Advisory } \\
\text { board }\end{array}$ & Other $^{3}$ \\
\hline $\begin{array}{l}\text { Leonardo A. } \\
\text { Sodré }\end{array}$ & HCPA/UFRGS & - & - & - & - & - & - \\
\hline Joana Bücker & HCPAJUFRGS & - & - & - & - & - & - \\
\hline Karine Zortéa & HCPAJUFRGS & - & - & - & - & - & - \\
\hline $\begin{array}{l}\text { Mireia F. } \\
\text { Sulzbach-Vianna }\end{array}$ & HCPA/UFRGS & - & - & - & - & - & - \\
\hline $\begin{array}{l}\text { Clarissa Severino } \\
\text { Gama }\end{array}$ & HCPA/UFRGS & $\begin{array}{l}\text { FIPE/HCPA* } \\
\text { FAPERGS* } \\
\text { CNPq }^{* *}\end{array}$ & - & Lundbeck* & - & $\begin{array}{c}\text { Actelion } \\
\text { Pharmaceutical } \\
\text { Ltd }\end{array}$ & $\begin{array}{l}\text { Eli-Lilly } \\
\text { Jansen- } \\
\text { Cilag }\end{array}$ \\
\hline \multicolumn{8}{|c|}{$\begin{array}{l}\text { *Modest } \\
\text { ** Significant } \\
\text { *** Significant: Amounts given to the author's institution or to a colleague for research in which the author has participation, not directly to the authol } \\
\text { Note: HCPA/UFRGS = Hospital de Clínicas de Porto Alegre da Universidade Federal do Rio Grande do Sul; FIPE/HCPA = Fundo de Incentivo á } \\
\text { Pesquisa e Eventos do Hospital de Clinicas de Porto Alegre; FAPERGS = Fundação de Amparo á Pesquisa do Estado do Rio Grande do Sul; } \\
\text { CNPq = conselho nacional de Desenvolvimento Científico e Tecnológico. } \\
\text { For more information, see Instructions for Authors. }\end{array}$} \\
\hline
\end{tabular}

References

1. Bressan RA, Pilowsky LS. Glutamatergic hypothesis of schizophrenia. Rev Bras Psiquiatr. 2003;25(3):177-83.

2. Gama CS, Berk M, Andreazza AC, Kapczinski F, Belmonte-de-Abreu P. Serum levels of brain-derived neurotrophic factor and thiobarbituric acid reactive substances in chronically medicated schizophrenic patients: a positive correlation. Rev Bras Psiquiatr. 2008;30(4):337-40.

3. Kapczinski F, Dias VV, Kauer-Sant'Anna M, Frey BN, Grassi-Oliveira R, Colom F, Berk M. Clinical implications of a staging model for bipolar disorders. Expert Rev Neurother. 2009;9(7):957-66.

4. Gama CS, Lucena D, Cruz C, Lobato MI, Belmonte-de-Abreu PS. Improvement of schizophrenia negative and positive symptoms with amantadine as add-on therapy to antipsychotics: a case series. Rev Bras Psiquiatr. 2010;32(2):193-4.

5. Ohlmeier MD, Zhang Y, Bode L, Sieg S, Feutl S, Ludwig H, Emroch HM, Dietrich DE. Amantadine reduces mania in borna disease virus-infected non-psychotic bipolar patients. Pharmacopsychiatry. 2008;41(5):202-3. 